\title{
IMAGES OF THE EUROPEAN UNION FROM THE PERSPECTIVE OF THE DEBATE HELD IN THE POLISH PARLIAMENT ON THE INFORMATION OF THE MINISTER OF FOREIGN AFFAIRS ON THE TASKS OF FOREIGN POLICY OF POLAND IN 2017
}

\author{
Dr. Krzysztof Cebul \\ Institute of Political Science \\ Cardinal Stefan Wyszyński University in Warsaw \\ krzysztofcebul@wp.pl
}

DOI:10.24193/OJMNE.2018.26.01

\begin{abstract}
:
This paper is an analysis of speeches delivered by the Members of Parliament in the Sejm of the Republic of Poland during the discussion which took place on $9^{\text {th }}$ February 2017 regarding the information from the Minister of Foreign Affairs about the tasks of the Polish foreign policy in 2017. The aim of the analysis focusing on parliamentary discourse was to reconstruct the images (visions) of the European Union created by the representatives of the main political powers in Poland. The analysis confirms that since 2007 there have evolved two separate images of the European Union in the Polish parliamentary discourse (EU as an area of rivalry/confrontation vs EU as a conciliatory Union), hence there have also been two different propositions of how Poland should participate in the integration process.
\end{abstract}

Keywords: parliamentary discourse, political divisions, integration process, full sovereignty, dependent sovereignty

\section{Introduction}

The aim of the study presented in this text is to re-create political discourse, that is the meanings of linguistic constructions - images (visions) of the European Union which arise in the communication process in the parliamentary debates and are created by categories of "place" and "role" of Poland in the system of the Union (perception of Poland's place and role in the EU). It should be pointed out that parliamentary debates create special conditions where, as a result of communication processes, the meaning of the language of politics is 
confronted and negotiated. Hence, it should be assumed that the study of a large amount of expanded utterances in a chronological system which are formed in similar conditions will help establish the structure (shapes) of these creations, the scopes of convergence and divergence between particular political stands as well as their determinants.

Such formulation of the aim determines the necessity to fulfil three tasks: 1) to specify the methodological assumptions of discourse analysis; 2) to reconstruct the internal and external discourse context - the context opening the possibility to make interpretation; 3) to establish, as part of the debate under analysis, the categories of meanings that organise discourse and to separate and put in order the stands by establishing the convergence and divergence of the formulated evaluations.

\section{The discursive dimension of political reality}

For the purpose of this paper, it is assumed that political discourse means the politicians' speeches which they deliver while fulfilling their roles in political institutions that is the speeches of persons belonging to the elites of power, the speeches which are related to their political roles and functions (Czyżewski at al., 2010, pp. 22-23).

The material scope of this paper is outlined by two categories of reference: the "place" and "role". They encompass the specific tension which exists between the thesis that countries have the power to independently act in the international area and the thesis that, in fact, their capabilities are determined by the structure of the international system (Czaputowicz, 2008, pp. 29-30). These concepts should be related to the active participation of the entity in the system. Their meanings indicate that they have some potential of creating possibilities. At the same time, they can be interpreted in the categories of objects, as a specific positioning which is only a consequence of mainly external circumstances and which should be accepted. Therefore, they should be acknowledged and it would be best to justify them somehow, hence to rationalise the existing status quo.

However, no matter these objections, it seems that the occupied place is a derivative of a role performed by a given entity. The "role" category includes a sort of meaning of the measure, that is the capacity, potential, strength and the lack of it, insignificance, susceptibility, subordination, and weakness. The said opposition, although it is usually not so clear since in politics independence is intertwined with dependence, is questioning how the 
organised political grouping, while being equipped with resources and mind, being motivated to act with a specific intent (Sułek, 2013, p. 49), is generally able to overcome barriers. So, the question is whether the will is powerful; does it have the capacity to change the surrounding, or does the environment (cumulation of its potential) define the limits of its capabilities? Hence, to some degree, does it shape, that is actually restrict, its will (defines its creative space)?

Stepping onto parliamentary discourse level, the above-mentioned categories, mainly the "place" and "role", may be treated as separate perceptions, as the ways of perceiving Poland in the European Union, as different visions that is actually different "places" and related "roles". This diversity and ambiguity indicates that there is a dispute concerning what constituted, constitutes and perhaps what should constitute political order, which brings to mind a relative unity (Waśkiewicz, 1998, p. 14). The concepts of "place” and "role” include, however, various concepts of political governance, which is - paradoxically and contrary to what "governance" should bring to mind - a contentious concept whose strong ambiguity, given and enhanced by the category of politics, is reflected in the contradiction of constructs (these constructs want to be deemed as exclusively applicable), the contradiction which gives this term, in a certain way, a discursive dimension (Waśkiewicz, 1998, p. 14). This dimension materialises itself during, for example, parliamentary debates.

But do the images (constructs) being studied have any value in the impenetrable complexity of the international system? As Andrzej Waśkiewicz proves, although linking the language of politics and political activities may have different forms, the key factor here is the relation with the shape of a given political reality - created reality and factual reality (Waśkiewicz, 1998, p. 14). Hence, these concepts, visions - the things which constitute an "idea-creating" activity, consisting of the designing of a desired political governance (Paruch and Trembicka, 2002, p. 8), the activity which in some aspects has a status of political thought - constitute in fact, yet often different, political emanations of the awareness of a diverse community.

These images located, as it would seem, at a quite unreachable, abstract level (as opposed to the level of political practice, that is real actions), therefore are actually part of political life and because of that, they gain a status of a "fact" (Waśkiewicz, 1998, p. 87). However, it is illegitimate to adopt the meaning which largely expands their impact 
capabilities, hence through caution, the texts should be treated as a record of "thinking activity" (Waśkiewicz, 1998, p. 87). This does not mean, in any way, that the text is detached from reality. The text is an emanation - a sort of manifestation of circumstances. If, however, each omission of the context enhances hypothetical and undefined political thought and restricts, or even makes it impossible to interpret events, the text should be treated as depending on circumstances in which it was written and read out or uttered, although obviously perceiving this relation is highly problematic (Waśkiewicz, 1998, p. 89). Therefore, it should be assumed that discourses contain representations of what reality could or should look like (Chiapello and Fairclough, 2008, pp. 386-387).

In this context, the fact worth noting is quite obvious, that any political institutions are human creations. It suffices to be able to mindfully discover these creations. Additionally, the susceptibility to change of these materialised political creations only confirms the creation capabilities of this idea which is defined in discourse level categories, since without such reflection they would need to have a static nature, external and impenetrable for society (Waśkiewicz, 1998, p. 13). These capabilities to create and change the social world (although limited) are undoubtedly proof of the word's strength. This is a linguistic picture - the speech is therefore a linguistic picture of the world (Bartmiński, 2008). Hence, the speech is a form (not necessarily clear), a reflection of this world. At the same time, it is the only form of the word that we have, by which our place in the world and our connection to the world is materialised. But this picture not only is not, but it cannot be coherent, since the oppositions and differences of the messages/solutions, non-obviousness that we experience, are an inevitable product of communication (Fleischer, 2005, p. 132), hence it is the reality's necessity to have various, non-reducible pictures.

In view of the dependencies as presented above, the possibility to apply discourse analysis in learning political reality directs our attention to a polito-linguistic approach which combines rhetoric, political science and linguistics (Reisigl, 2011, p. 153) and which refers mainly to its dimension 1) "policy" - that is the essence of political activity and 2) "polity" that is formal and structural frames of reference (Reisigl, 2011, pp. 153-154). So, it is obvious what should be underlined - that political discourse analysis is based on its dual structure. On the one hand, the linguistic dimension should be considered, and on the other hand - political relations which together form a proper discourse area (Rittel, 2005, p. 51). If this is the case, 
political discourse should be treated as an event generalised by the political system and simultaneously generating its verbal and extra-verbal meaning (Rittel, 2005, p. 24).

The determinants outlined above show that the assumptions of critical analysis of discourse of political messages seem to be extremely promising and combine the above specified dimensions (Howarth, 2008, pp. 16-17). The critical discourse analysis shows the tension which can be seen in the combination between meaning and materiality. This involves the combination formed in relation to the pressure created by the governing bodies. The pressure is reflected by the process of "reducing our freedom" (Fairclough and Duszak, 2008, p. 10) and directs the investigator's attention to social discursive processes, such as relations, systems and structures (Fairclough and Duszak, 2008, p. 15). Taking the approach that the social world is socially construed (Faircloug and Duszak, 2008, p. 8), hence that the discourse is a driving force in the ongoing process of Poland's integration with the European Union, all issues related to this process focus on "the central dialectic axis". This axis is defined by such categories as: the “creation”, “consolidation”, “reproduction” and "transformation" of social phenomena being in the range of its impact. In view of the perspective outlined in this way, the primary postulate of the study should be to see the dialectic relation between meaning and materiality (Fairclough and Duszak, 2008, p. 8).

\section{The analysis of political discourse (taking into account its contexts) during the} discussion held on $9^{\text {th }}$ February 2017 in the Polish Sejm

The perspective which can help us to explain the textual reality is provided by the systemic approach. Here, the system is understood as a type of perceptual construction through which the investigator (but also participants in language practices of parliamentary debates) strives to put in order (understand) parliamentary reality (Dahl and Stinebrickner, 2007, p. 51). However, it should be noted that systems are not static by nature. Therefore, systems should be treated as specific "structural processes" covering also transitions, transformations and structures (Dahl and Stinebrickner, 2007, p. 52). Accordingly, foreign policy should be treated as a social process which (in short) is created by structures of three co-depended areas: 1) internal system of the country where foreign policy is initiated; 2) international environment where it is pursued; and 3) social level where it is verified (Zięba, 2007, p. 387). Yet, special attention should be paid here to the two often contradictory trends: 
1) the country's drive to obtain an optimal international position and 2) the pressure put by the international environment on state bodies, in fact by the bodies which have gathered and are able to maintain greater potential than other bodies (Koziełło, 2011, p. 39). Adopting such a perspective allows to perceive Poland as a subsystem through which a desired efficiency is partially obtained. However, more opportunities to achieve such efficiency are determined by the impact of the surrounding environment. It is out of necessity that they are completed in the country's connections with external entities. Such a functional and at the same time limited in a sense (which should be emphasised) surrounding environment for Poland is the European Union (the structure of mutual links and dependencies which comprise the EU).

Following the elections to the Sejm and Senat held on $25^{\text {th }}$ October 2015, Law and Justice (Prawo i Sprawiedliwość - PiS) gained 235 mandates in the Sejm. PiS gathered the majority in the Sejm, which allowed them to form an independent government. In the Sejm there were also: Civic Platform (Platforma Obywatelska - PO) - 138 mandates, Kukiz'15 (K’15) - 42 mandates, Modern (Nowoczesna Ryszarda Petru - N) - 28 mandates, Polish People's Party (Polskie Stronnictwo Ludowe - PSL) - 16 mandates, German Minority (Mniejszość Niemiecka) - 1 mandate (Elections Outcomes, 2015). A consequence of the political change which took place as a result of parliamentary elections was the switch in respect of the perception of the place and role of Poland in the international surrounding, mainly in the area of the European Union. One can notice a departure from the conciliatory vision of the EU (the rule of PO-PSL in the years 2007-2011 and 2011-2015) and the return to the concept of sovereignty indivisibility pursued in 2005-2007 (initially as a minority government of PiS, later as a coalition of PiS, League of Polish Families [Liga Polskich Rodzin] and Self-Defence of the Republic of Poland [Samoobrona Rzeczpospolitej Polskiej]).

A category useful to explain the situation in Poland after the disintegration of the Eastern Block may prove to be the peripherality. It allows to describe specific relations of Poland with the centre that is with the European Union. The separation of Poland for almost half of the $20^{\text {th }}$ century from the world system (connections within socialist countries system) determined Poland's peripherality, in both the factual and the mental dimension (Gawrycki and Szeptycki, 2011, pp. 231-232). An increasing dysfunctionality of Poland which was caused by a sudden entry in 1989 into the circle of the world capital system only revealed 
even more its incompatibility with the surrounding environment (Staniszkis, 1995, p. 47). Poland's own resources proved to be insufficient to carry out profound adaptation changes. Faced with this issue, the offer of the western countries from the beginning of $20^{\text {th }}$ century which promised modernisation gave Poland hope to overcome its peripherality. It was in fact a necessity, since there was no alternative for a country detached from the new international arrangement. However, this offer required the implementation of numerous solutions that would make the Polish system more compatible with western structures. By accepting this offer, Poland became at first the client of the Communities, and later the client of the European Union, and since $1^{\text {st }}$ May 2004, while gradually “learning” the Union, became a participant in the integration process searching for its own place in the integration environment and trying to define its role in the new system (Cebul, 2018, p. 428).

A consequence of the lack of alternative for the integration with the EU was accelerated adaptation and a lack of immunity to disturbances of quite a weak integration compromise. Moreover, the pressure of the Union to modernise Poland, reflected in the transformation process coupled with integration processes, imposed a liberal market logic as a binding one, which limited the extent of perception of integration to an economic dimension which was adjustable to its own requirements. Consequently, internal transformations were under the impact of external logic.

But since $1^{\text {st }}$ May 2004, Poland, by being included in the union system, from the position of being solely the Union's client, has gradually become a co-creator of the integration process, but at the same time was a territory susceptible to the impact of integration. In other words - a place where the country's strength clashes with the pressure to integrate. Since the breakdown of the integration compromise, whose symbol was marked by the parliamentary elections in 2001, when the groups challenging both the existing transformation direction and the-then Poland's integration achievement - the field of political discourse was polarised by two different images of the integration process. This dichotomy became especially clear before the elections in 2007 and, as subsequent analyses of debates in the Sejm confirm (Cebul, 2017), has remained until today.

Different images are the basis for various assessments of the transformation process initiated in 1989 in Poland. The first among these directions enumerates the achievements of the transformation period which preserved the continuity (mainly PO and PSL), while the 
second direction focuses on systemic dysfunctions of the transformation period underlining an absolute need for in-depth reconstruction (predominantly PiS). The essence of the dispute is the fact that there are different perceptions of Poland's potential: cumulation and continuation (PO and PSL) or breaking and building from scratch/possibly re-building (PiS), respectively. On the basis of these perceptions, images of the European Union arise as well as postulates regarding the place and role of Poland in the Union (Cebul, 2018, p. 432).

The analysis of the debate held in the Sejm on $9^{\text {th }}$ February 2017 concerning the information of the Ministry of Foreign Affairs about the tasks of the Polish foreign policy in 2017 (Speeches, 2017) shows that in the Polish parliamentary discourse there are separate images of the Union, hence also two different propositions regarding the manner of Poland's participation in the integration process. The differences in this respect define a permanent division between PiS, on the one hand (postulating to achieve full sovereignty, independence of the country), and PO, N and PSL, on the other hand (accepting the necessity of dependent sovereignty which is co-created by the EU Member States). The analysis confirms the above specified persistence of images which have been observed in the Polish parliamentary discourse since 2007, consisting of two clearly separate images of the Union: 1) the EU as an area of rivalry/confrontation (PiS) vs 2) the Union of coalition (PO) and therefore - also two contrary propositions as to the manner of Poland's participation in the integration process. The position of K'15 should be situated outside the scheme described above, since this club rejects both the concept of foreign policy of PiS and the policy of PO-PSL which was previously pursued- accusing these groups that they lack the vision of the Polish raison d’État.

PiS invokes the category of decisional independence directly stemming from the classic concept of sovereignty. According to this concept, the sole entity capable of resolving the key decisions to a certain extent is the state. Limiting these powers, as PiS claims, in fact eliminates the subjectivity. In this case, the state becomes a passive object in the integration sphere, gradually dependent on other states. The Union is perceived by these groups dually: 1) as a quite effective area of security and at the same time 2) as a surface where different interests of various Member States clash (rivalry), that is an area not actually for co-operation and integration, but an area of fight for domination (to seize the rule over the Union's system). It seems that the adoption of this, somehow discordant, construction enables one to 
acknowledge that the internal rivalry is a kind of process streamlining the EU system and it does not threaten the durability of the integration project. Hence, the participation in the Union’s system is rather determined by exclusive preference for Polish national interest.

$\mathrm{PO}, \mathrm{N}$ and PSL, in turn, use a modified concept of understanding the independence. The sovereignty seen in this way is not perceived from the particular perspective of a state but from the perspective of a country placed in the structure of connections. Here, the essential need is to reduce the contradictions of the relations between entities that form the Union's system. In this case, the independence which is characteristic of the sovereignty of a state, in the light of the classic concept, is located on the superior level (EU). Such a shift causes that the manner of perceiving Poland's position (potential) is a derivative of the evaluation/condition of the potential of the entire Union's system. It should be emphasised that this type of co-dependency is treated as an objective necessity, apart from which Poland has no alternative. This specific sort of unity in the EU is also a sort of guarantee of safety for Poland. The maintaining of the co-dependency of the state is to be guaranteed by being in the so-called main integration stream (a guarantee to be in this stream is, inter alia, the cooperation with Germany in the crucial issues for the Union). To break out from this stream means to weaken the Union.

During the debate, PO submitted a motion to reject the information of the Minister of Foreign Affairs about the tasks of the Polish foreign policy in 2017. The Sejm dismissed this motion and accepted the information of the Minister of Foreign Affairs. In the voting, 432 deputies took part. The outcomes of the voting were as follows: 190 deputies voted in favour of the motion to reject the information (PO - 118, K'15 - 26, N - 28, PSL - 14, Union of European Democrats [koło Unii Europejskich Demokratów - 4), 231 deputies voted against the motion (PiS - 227, non-party members - 2, Free and Solidary [koło Wolni i Solidarni] 2), 11 deputies abstained from voting, 28 deputies did not vote (Voting, 2017).

\section{Bibliography:}

- $\quad$ CEBUL, K. (2017) The place and role of Poland in the international security system in the light of parliamentary discussions on information provided by minister of foreign affairs on tasks of foreign policy between 2006 and 2016. In: RUDOWSKI, A., SULKOWSKI, M. (eds.) Poland in the European Union - perspectives of membership 
Politics: Economy and Society. Culture. International Relationships. Trans by M. Karliński, A. Lewoc. Warsaw: Cardinal Stefan Wyszyński University Press, pp. 158-171 [Online] Available from: http://www.wydawnictwo.uksw.edu.pl/sites/default/files/Poland\%20in\%20the\%20European \%20Union\%20-\%20perspectives\%20of\%20membership\%20-\%20wersja\%20oficjalna.pdf [Accessed 03/04/2018].

- CEBUL, K. (2018) Miejsce i rola Polski w Unii Europejskiej w świetle debat parlamentarnych w Sejmie RP w latach 2004-2011. Warszawa: Wydawnictwo Naukowe UKSW.

- $\quad$ CHIAPELLO, E., FAIRCLOUGH, N. (2008) Nowa ideologia zarządzania: podejście transdyscyplinarnej krytycznej analizy dyskursu i nowej socjologii kapitalizmu. Trans by K. Stefaniak. In: DUSZAK, A., FAIRCLOUGH, (eds.) Krytyczna analiza dyskursu: interdyscyplinarne podejście do komunikacji społecznej. Kraków: Universitas, pp. 373-404.

- CZAPUTOWICZ, J. (2008) Teorie stosunków międzynarodowych: krytyka i systematyzacja. Warszawa: Wydawnictwo Naukowe PWN.

- $\quad$ CZYŻEWSKI, M., KOWALSKI, S., PIOTROWSKI A. (2010) Wprowadzenie. In: [w:] CZYŻEWSKI, M., KOWALSKI, S., PIOTROWSKI, A. (eds.) Rytualny chaos: studium dyskursu publicznego. Warszawa: Wydawnictwa Akademickie i Profesjonalne, pp. 15-47.

- $\quad$ DAHL, R. A., STINEBRICKNER, B. (2007) Współczesna analiza polityczna. Trans by P. M. Kazimierczak. Warszawa: Wydawnictwo Naukowe Scholar.

- $\quad$ GAWRYCKI, M. F., SZEPTYCKI, A. (2011) Podporządkowanie - niedorozwój wyobcowanie: postkolonializm a stosunki międzynarodowe. Warszawa: Wydawnictwa Uniwersytetu Warszawskiego.

- VOTING (2017) Głosowanie nr 2 na 35. posiedzeniu Sejmu dnia 10-02-2017 r. o $\begin{array}{llll}\text { godz. } & 11: 24: 24 & \text { [Online] from: }\end{array}$ http://www.sejm.gov.pl/Sejm8.nsf/agent.xsp?symbol=glosowania\&NrKadencji=8\&NrPosied zenia=35\&NrGlosowania=2 [Accessed 03/04/2018].

- $\quad$ KOZIEŁŁO, T. (2011) Międzynarodowa rola Polski w polityce rządów RP od 1989 roku. In: JAROSZ, A., OLSZEWSKI, K. (eds.) Polityka zagraniczna III RP. 20 lat po 
przełomie: koncepcje, bezpieczeństwo, kwestie prawne i polonijne. Vol no 1. Toruń: Wydawnictwo Naukowe Uniwersytetu Mikołaja Kopernika.

- $\quad$ PARUCH W., TREMBICKA, K. (2002) Wprowadzenie. In: PARUCH, W., TREMBICKA, K. (eds.) Wizje i realia: studia nad realizacja polskiej myśli politycznej XX wieku. Lublin: Wydawnictwo Uniwersytetu Marii Curie-Skłodowskiej, pp. 7-15.

- REISIGL M. (2011) Analiza retoryki politycznej. In: WODAK, R., KRZYŻANOWSKI, M. (eds.) Jakościowa analiza dyskursu $w$ naukach społecznych. Trans by D. Przepiórkowska. Warszawa: Wydawnictwo Łośgraf, pp. 151-183.

- $\quad$ RITTEL, S. J. (2005) Dyskurs $w$ filozofii politycznej: podejście lingwistycznopolitologiczne i systemowe. Kielce: Wydawnictwo Akademii Świętokrzyskiej.

- $\quad$ STANISZKIS, J. (1995) Polityka postkomunistycznej instytucjonalizacji w perspektywie historycznej. Part no 1. Studia Polityczne, 4, pp. 39-60.

- $\quad$ SUŁEK, M. (2013) Potęga państw: modele i zastosowania. Warszawa: Wydawnictwo Rambler.

- WAŚKIEWICZ, A. (1998) Interpretacja teorii politycznej: spór o metodę we wspótczesnej literaturze anglosaskiej. Warszawa: Wydawnictwo Naukowe Scholar.

- $\quad$ ELECTION RESULTS (2015) Wyniki wyborów do Sejmu RP [Online] Available from: http://parlament2015.pkw.gov.pl/349_wyniki_sejm [Accessed 03/04/2018].

- $\quad$ SPEECHES (2017) Wypowiedzi na posiedzeniach Sejmu: posiedzenie $n r 35$ w dniu 09-02-2017 (2. dzień obrad) [Online] Available from: http://www.sejm.gov.pl/Sejm8.nsf/wypowiedz.xsp?posiedzenie=35\&dzien=2\&wyp=0\&view =1 [Accessed 03/04/2018].

- $\quad$ ZIĘBA, R. (2007) Paradoksy polityki zagranicznej Polski w okresie transformacji. In: Karwat, M. (ed.) Paradoksy polityki. Warszawa: Dom Wydawniczy Elipsa, pp. 285-313. 